\title{
KUTÓ-KUTÉ PERSONAL PRONOUN
}

\author{
By: \\ Muhammad \\ Lecturer in Ahmad Dahlan University of Yogyakarta \\ Doctoral Student of Linguistics Department \\ Postgraduate Program, Sebelas Maret University \\ E-mail: staywithus22@gmail.com
}

\begin{abstract}
Forms, meanings, dialects, and characteristics of Sasak language Pronouns were discussed by Nurhadi (1996), Sukmawati, (2004) and Riadatul Jannah (2004). Hence this research paper describes a social factors, personal pronoun, and how Bayan speakers communite with. Alternatively it would like to focus on socio-cultural factors of Bayan personal pronouns. This ethnographical research gathered the information from the informants in a Bayan community in north Lombok, west Nusa Tenggara, and Indonesia. The informants were selected in terms of their age, mobile and their speaking Indonesia ability. The language practice was observed and the informants were in-depth interviewed. Personal pronoun sentences were analysed by employing a referential identity method with deviding-key-factors techniques. Bayan people communicate pronouns in three ways: raden-tomenak-to-jajarkarang, jajarkarang-to-menak-to-raden and raden. menak. jajarkarang. They apply various speaker, addressee and object personal pronouns, e.g. aku, tiang, titiang and dawekdiq, kamu, epe, sida, pelinggih, and pelungguh. pragayan, and batayan, iya, nya, $e$. Communicating amongst same stratification, they commonly consider ages, position, and status. However social relation, and gender seemed not to indicate an effect on personal pronoun application.
\end{abstract}

Keywords: Sasak, Bayan, raden, menak, jajar karang, pronouns, social level, ages, status, and education.

\section{INTRODUCTION}

Forms and functions of Sasak pronouns were investigated by Nurhadi (1996). His research in South east area of East Lombok perfecture analyzed the pronouns in terms of social stratification, clan system, social status, and social position (Cf. Mariati (2009:4). Forms, functions and meaning of demonstrative pronouns were discussed by Dian Sukmawati (2004). (Cf. Mariati, 2009:4). In other words, this research focuses on linguistic aspect 
instead of social aspect of language use. Forms, features, functions and meanings of interogative pronouns were described by Riadatul Jannah (2004). This research was done at Dusun Senggigi Kecamatan Batu Layar, West Nusa Tenggara (Cf. Mariati, 2009:4). Thus Riadatul Jannah focused on only linguistic aspect rather than social factors of language in certain dialect of Sasak language. Personal pronouns used by Sukadana people in North Lombok were investigated by Mariati (2009). The research focuses on forms, rather than how the people apply personal pronoun in Sukadana.

Sasak has five dialects namely menó-mené, ngenó-ngené, kutó-kuté, ngenó-menó, and meriak-meriku. The meaning 'like this' is represented by meno, 'like that' mene. Additionally, the dialects use terms meno, ngeto, and ngeno something close to mene, and ngete. They use different lexemes; the former classification uses kuto-kute, while the latter ngeto-ngete Arzaki and Tohir et.al. (1986) in Mahsun (2006:3) via Muhammad, (2012:56).Bayan is a village in North Lombok, West Nusa Tenggara. The people speak Sasak, a Western Malayo-Polynesian language which is closely related to Samawa, and Balinese. Samawa is spoken on the western half of the island of Sumbawa to the east of Lombok. Balinese is a sub-group, a member of the western-Malayo-Polynesian branch of Austronesian (See Adelaar, 2002)(B. Blust,n.d.) via (Cf. Muhammad, 2012:6).

Dialect Ngenó-Ngené is used in the western part of Lombok. Menó-Mené dialect is spoken around Pejanggik. Meriaq-Meriqu is used by the Sasak people who live in Pujut, South Lombok. The Kuté-Kuté dialect is in Bayan, in the northern part of the Island of Lombok. The Ngetó-Ngeté dialect is spoken in Sembalun or Seralaga, the east Lombok.Lalu Mahir (1993:3) via (Muhammad, 2012:6). The following map shows Bayan or Kuté-Kuté dialect.

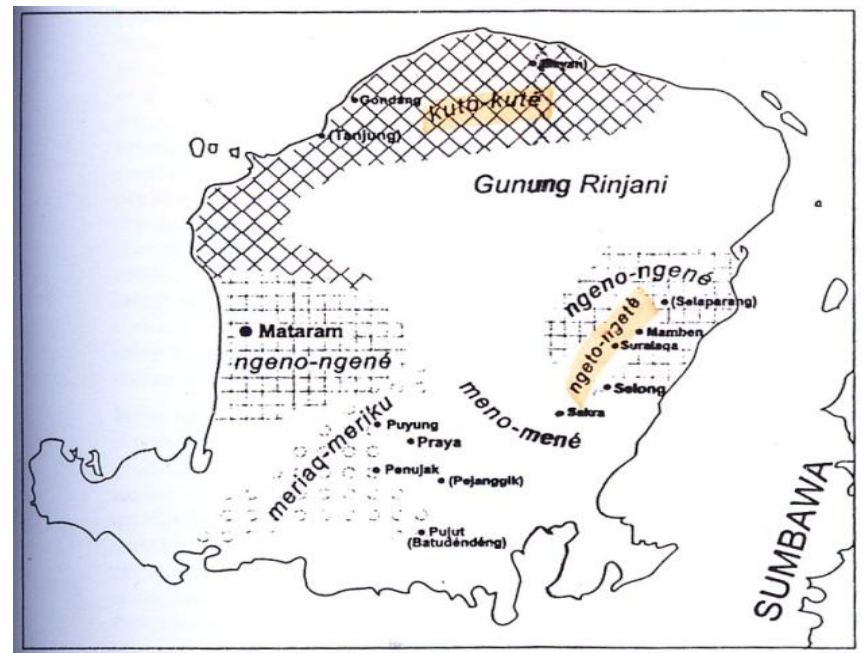

(Austin (2000) via Muhammad, 2012:6). 
Bayan is a village and a district in North Lombok, West Nusa Tenggara. In Bayan live four etnic groups, such as Java, Sasak, Bugis, Mbojo, and Bali. Bugis people live along the beaches as they are sailors. They also speak three languages, namely Sasak, Bugis, and Melayu (Cf. Mariati, 2009:13).

Additionally, Mbojo and Bali people work as the officers,e.g. police, teachers, doctors. Particularly, Bali people are talent farmers, living on foot of Rinjani mountain, and making Gubug Bali or Bali Community (Cf. Mariati, 2009:13).

Bayan village has Kampung Raden, where Raden and Dende hold their addresses or titles. Besides they speak different level of language, e.g. personal pronoun, considering the counterparts' social status. (Cf. Mariati, 2009:13). This village exists in Bayan district bordered by Java sea in the north area. The district is also bodered by east Lombok prefecture in the east, central Lombok prefecture in the south, and Kayangan in the west (BPS Kabupaten Lombok Utara, 2011:3).

The district consists of 9 villages, namely Akar-Akar, Sukadana, Anyar, Senaru, Bayan, Loloan, Mumbul Sari, Sambik Elen, and Karang Bajo. Each village has their own width, such as 49,00 $\mathrm{Km}^{2}$ for Akar-Akar, 45,90 $\mathrm{Km}^{2}, 45,90 \mathrm{Km}^{2}$ for Sukadana, 9,96 $\mathrm{Km}^{2}$ for Anyar, Senaru, 41,62 $\mathrm{Km}^{2}, \mathbf{3 7 , 1 6} \mathrm{Km}^{2}$ for Bayan, $30,00 \mathrm{Km}^{2}$ forLoloan, $25 \mathrm{Km}^{2}$ for Mumbul Sari, $41 \mathrm{Km}^{2}$ for Sambik Elen, and 11,68 $\mathrm{Km}^{2}$ for Karang Bajo. (BPS Kabupaten Lombok Utara, 2011:3). Bayan village has 13 sub-villages with 29 family groups. It has also 8 village officers with 9 head-villager, 29 chiefs of house groups, one penghulu, and 9 pekasih $^{1}$. It has 4.447 people, consisting of 2.160 males and 2.317 females according to population census in 2010 (BPS Kabupaten Lombok Utara, 2011:12, and 22).

It has 1.269 house holds, consisting of 459 people with 0-4 in age, 505 people with 59 in age, 469 people with 10-14 in ages, and 379 people with 15-19 in ages, 372 people with 20-24 in ages, 416 people with 25-29 in ages, 312 people with 30-34 in ages, and 300 people with 35-39 in ages,309 people with 40-44 in ages, 217 people with 45-49 in ages, 175 people with 50-54 in ages, 140 people with 55-59 in ages, 139 people with 60-64 in ages, and 293 people with 65+ in ages. (BPS Kabupaten Lombok Utara, 2011:27-30).

\footnotetext{
${ }^{1}$ Term Pekasih and Penghulu refers to 'profession' possessed by village people in Lombok. Generally they work to give a religious service, and irrigation service. They are selected for having attended moslem teaching and high class society. 
In Bayan one Inpres and Non-Inpress elementary schools exists ${ }^{2}$. The village has 24 teachers with 528 pupils. It has not a state yunior and a state senior high school. There is one Islamic elementary school called Madrasah Ibtidaiyah, possessing 8 teachers and 80 pupils. An Islamic yunior high school exists in Bayan, having 16 teachers and 36 students. No Islamic senior high school exists in the village. Eight ${ }^{3}$ Posyandu occurs in Bayan. One Bidan and 5 Dukun Bayi ${ }^{4}$ exist in Bayan. Joget or tari and music are in the village. (BPS Kabupaten Lombok Utara, 2010:34, 51-61). Bayan has low education level, few health centres, care for arts.

In Bayan village exist three social stratifications: raden, menak and jajarkarang. Raden belongs to king and queen including their descendants. There is not kingdom in Bayan anymore, however the practice of kingdom life, e.g. language could still be found. Menaq belongs to aristocrats, and their family who could have gotten married with the lower class or Jajarkarang people. Jajarkarang iscommon people, who generally have not certain noble address. Raden refers to a high level, menaq a middle level and jajarkarang low stratification.

My observation and interview indicated that Raden has a kaji-meran language. Kaji means 'I' and meran 'apa' This variety is a high and polite language and I would call it baso Raden or basə Datu. Menak people speak tiang-nggih, a middle polite language in Bayan society. Tiang means 'I' and nggih 'yes' and I would name it basə Menak.Jajar karang people speak aoq-apa language. Aoq means 'yes', apa means 'what' and this language would be termed as basə jamak. Common people apply a low language. Thus Bayan has basə Raden, menak and jamaq. ${ }^{5}$

Pronoun is "a word that replaces a noun". Furthermore, a personal pronoun refers to "Pronoun denoting person" (Harimurti Kridalaksana, 2011:200-1). Thus pronoun is related word indicating persons. The personal pronouns consist of three types: first, second, and third person. Each type is grouped into singular and plural. (Mariati, 2009:7).

\footnotetext{
${ }^{2}$ Inpress and Non-Inpress refers to schools which are 'managed' by Goverment and Private, i.e. foundation. ${ }^{3}$ Posyandu is an acronym for pos pelayanan terpadu 'an integral service centre' concerning with health service. ${ }^{4}$ Dukun Bayi and Bidan refers to baby birth. At some places in Lombok dukun bayi is called Bəlian.

${ }^{5}$ Baso is my term meaning language. Radenrefers to high social status, and Datuis King or official goverment. Menakrefers to lower society in rank or status compared to Raden. Jajarkarang refers to common people using jamaq (common) language. Accordingly I group the language into three: baso Raden, Menak and Jamaq. Two former languges are based on the communicants; and the latter is based on commonly language used by the people.
} 
In Bayan the first singular speaker applies personal pronouns: aku, tiay, dawok, and kaji. They also have a phrase form, namely dawak tian. The first plural speaker may apply one form, namely ita with two varieties $t a$ and $t$. These varieties may become prefix and suffix attached to any words. Ita may become first person pronoun (Mariati,2009:18). Besides Ita, Bayan plural pronouns are formed by combining two first singular base pronouns, and recapitulate the pronoun partially. Besides, other base form could combine with partial recapitulation pronoun. These pronouns are like aku-aku, tiay-tiang, kaji-kaji, ita-ita, titiay, and dawaq titiay. A full recapitulation form may combine with one of the words lonto, doang, kanyan and denote first singular person,e.g. aku-aku lonto, ita-itakanyan etc. (Mariati,2009:19)

The base pronoun may also combine with one of words pada, sami, solapuq respectively and become aku pada, tiay selapuk, dawaq tiay etc. Phrase first pronoun may combine with word sami 'all' as in dawaq tiay sami, and dawaq titiay sami. In Bayan, to show plural pronoun, first polite singular person and second honorific singular person may combine, as in tiay palingih and palingih tiay, tiay peluyguh and peluyguh tiay. The word titiay always co-occur with peluyguh and becomes titiay peluyguh. (Mariati,2009:20-1). Accordingly, Bayan first person pronouns variously consist of singular and plural forms. First plural forms are made through partial or full recapitulation, first or second pronoun combinations, other words combination with word or phrase pronouns.

Bayan has second singular and plural pronouns. The singular pronouns are diq, epe, sida, palingih, and peluyguh. Pronoun sida and diq has clitics $d a$ - and $d \partial$ - meaning "you". Singular pronoun may be a phrase in form, e.g. pragayan peliggih, and pragayan paluyguh meaning "you". The clitics forms may combine with word kaji and become dəkaji. Pronoun

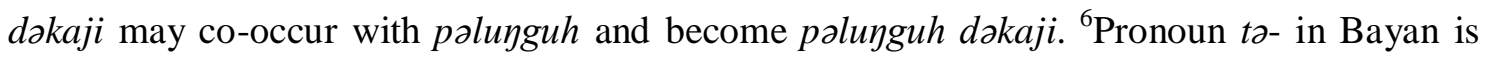
demonstrative transposition. (Cf.Mariati,2009:23-24). Thus Bayan second singular pronouns have base form, phrase forms, and clitics forms.

Second plural pronouns are pada. They also have recapitulated base singular pronouns i.e. diq-diq, epe-epe, sida-sida, palingih-paluyguh, and paluyguh-paluyguh. These recapitulated pronouns may combine with pada or selapuqan, such as sida-sidasalapuqan,

${ }^{6}$ This form is not only personal, demonstrative pronoun, but also prefix.

UNS Journal of Language Studies

Volume 02, Number 02, NOVEMBER 2013 
sida-sida pada etc. Recapitulated pronouns are used to show plural and emphasis (Cf. Thoir, 1985:93) via Mariati, (2009:26).

Bayan also has third singular and plural personal pronouns, i.e. iya, nyae, iya-iya, nya-nya, iya pada, nya pada, iya selapuq, and nya selapuq. Thus third personal pronouns may have base, recapitulated and other word combination forms.

Sentence refers to " a relative linguistic unit that can stand by its own self, and have final intonation. It also consists of a clause" Cook, (1971:39-40;Elison, and Pickett 1969:82) via Henry Guntur Tarigan, (1983:5). Thus linguistic units, intonation and clause are sentence components. A following example is mine.

Tian lalo bə =kədeq. (meno-mene dialect)

$1^{\text {rstplt }}$ go Int play.

'I went to hang around'

Sentence Tiay lalo bakadeq consists of word Tiay, lalo, and bakadeq ended with a flat intonation. The sentence could be developed and become a clause like Tiay lalo bakadeqpas na datəy musim ujan. The former linguistic unit is a clause which is a part of the latter one. It could be transformed into a question like sai lalo bəkədeq 'who went to hang around'. This question requires an information on the goer.

\section{RESEARCH METHOD}

This is a descriptive qualitative research. Data based on observation, interview and introspection were transcribed for an analysis. The methods were to gather information in relation with three questions: (1) social factors (2) personal pronouns in Bayan, North Lombok, West Nusa Tenggara and (3) personal pronoun use.Data were gathered by an observation, an interviewing and an introspecting method with the observing and interviewing, recording, transfering, and transcribing technique (Cf. Muhammad, 2011:191200). They were collected from Bayan people with 25-65 year in age, having graduated at least elementary yunior high school education, and being healthy and able to speak bahasa Indonesia. Data were classified in terms of social factors in applying personal pronouns. Sentences were analyzed by a referential identity method with deviding-key-factors techniques where the researcher applied theories on social factor, personal pronouns and sentence. Linguistic intuition is also applied as the native speaker, (Cf. Muhammad, 2011:224-6 and 231). A system of Bayan personal pronoun use resulted and presented informally (Cf.Muhammad, 2011:231). It would be dispalyed in the ordinary words. 


\section{RESULT AND DISCUSSION}

The result could show and offer framework to understand: (1) social factors (2) personal pronouns (3) how Bayan people apply their personal pronouns. These questions will be described in the coming sections.

Bayan societies communicate with various personal pronouns. They consider social factors in applying them: speakers'condition, ages, gender, status, and social relationship, applying three types of personal pronouns: singular, plural speaker, addresse and 'object'. Speaker pronouns are like aku, tiang, dawek, kaji, ita, dawək tiaク. Addressee pronouns are

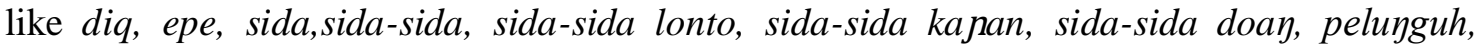
peliggih, pragayan, epe diq, kamu. Object pronouns are like iya, nya, iya-iya, nya-nya, iya pada, nya pada, iya solapuq, nya salapuq and $e$. Bayan people in north Lombok, west Nusa Tenggara apply three ways communicate with their personal pronouns. The strategies would bedescribed in the following sections.

\section{a. Raden-to-menak-to-jajarkarang}

Raden-to-menak-to-jajarkarang refers to a hierarchical communication among the participants. In Bayan when becoming speaker, Raden, Menak and Jajarkarang considered social factors to communicate their personal pronoun. A raden speaker seemed to apply $a k u$ to menak addressee. Menak speaker would also use aku to Jajarkarang addressee. Number (1) exemplifies $a k u$.

(1) Aku dait inak laló mbait képén nó $1^{\text {st low }}$ with mother go take money that

'My mother and I go to take the money'

Reversely, Jajarkarang would never speak $a k u$ to raden, and menaq. He or she could not state aku dait inak laló mbait képéy nó to them becouse it is considered to become rude or less polite.

In Bayan, raden, menak and jajarkarang speakers commonly apply ita, ta and te which mean 'we', the exlusive pronoun. Young speakers may apply ita to older ones. Amongst the levels, the speakers also use them to refer to first plural speakers. The example is as in (2.a-e):

(2) a. Baréh lai? ita laló sikiran aró balé=n ama =n Rinóm

Later afternoon we go pray to house POSSfather Asml Rinom 
'We go to Mr. Rinom's house to perform a prayer this afternoon'

b. Tapacu-pacu uli mun kón gubuk rəyan nó

$1^{\mathrm{pl}-\mathrm{excl}}$ diligent yes if ahouse group people that

'we have to behave very well in someone's land'

c. Mele $=\mathrm{n}=$ ta su milu lalo mengawe nó

Want link $1^{\text {pl-excl poss }}$ okay follow go party that

'we want to join going to the party'.

d. Mbe-mbe keputusan tau lokaq to =milu doang

Whatever decision people old $1^{\text {pl-excl }}$ follow only

'We will follow whatever decision made the old people'

e. Mbe kon =tə mənjojaq bareh daiq te əke

Where place $1^{\text {pl-excl-poss }}$ play later afternoonlater

'where would we like play this afternoon at?

In the example (2.a-e) ita, $t a,-t a$ and te seem to alert for internal linguistic aspects rather than social factors ${ }^{7}$ (Cf. Mariati, 2009:18).

\section{b. Jajarkarang-to-menak-to-raden}

Jajarkarang-to-menak-to-raden refers to a hierarchical communication among the parties. In a Bayan village communication Jajarkarang speaker could apply titiay to speak menak addressee. Word titiay is a polite form and $a k u$ is jamaq form. Menaq speakers may use it to Raden addressee. They could also apply dawak titiay to the addressee. Menaq speakers could apply both titiayand dawak titiayto Raden addressee. These pronous are polite forms including an addressee, meaning 'kami' in Indonesia.

In a formal situation Raden or menaq speakers could apply titiay and dawək ${ }^{8}$ titiay to the audience. These pronouns are thus applied to addressee for age, education, status, and situation. Number (3)-(4) is the example.

${ }^{7}$ Internal linguistics aspect would be focus of another study.

${ }^{8}$ Dawa $q$ could be frequently applied in a formal situation as claimed by Mariati (2009:31). 
(3) Tabeq wala ${ }^{9}$ ti $=$ tian kəte nunas mendoqa

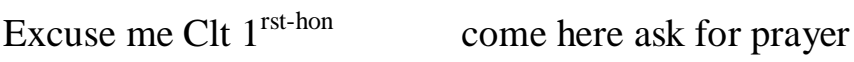

'excuse me, we visit you here to have your prayer'

(4) Tabeq wala daweq ${ }^{10}$ ti $=$ tian kəte nunas mendoqa

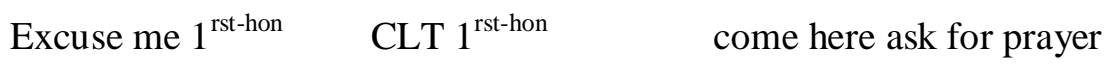

'excuse me, we visit you here to have your prayer'

Menak and Jajarkarang speakers can apply tiay-tiay and kaji-kaji to Raden addressee. Pronouns seem to be recapitulated for speaker number, age and the receiver. Bayan speakers of any social background would apply the pronouns, which could be combined with lonto or doay or kanan. This pronoun combination seem to indicate that a person performs an action frequently. Thus exclusive first plural person in Bayan community are made by recapitulating pronoun base, and combining with the other words. Number (5)-(7) is the pronoun example.

(5)Kəmbe keno aku-aku lonto piaq suruq

Why $1^{\text {rst-pl-excl }}$ only make order

'Why do you order only me to do the job?

(6) Bəyaq ita-ita kanyan suru =ay te

Why $1^{\text {rst-pl-excl }}$ onlyorder BEN PASS

'Why do you always order me to do the job?

(7) Kəmbe keno inaq kaji-kaji doang piaq aduay dait kana nunu cobaq suru =ay kakayku no

Why Mother $1^{\text {rst-pl-excl }}$ only make order with boy that try order BEN sister that

Jajarkarang speakers communicating with other Raden addressee use kaji pada. Raden and Jajarkarang speakers communicate with aku selapuq, ita selapuq, tian selapuq, and kaji selapuqto addressees in a formal situation. These pronouns may be applied for addressee, condition, and the speaker social stratification. Number (8)-(11) is the example of such pronouns.

${ }^{9}$ ti is a clitics of tiay, a loan word from Balinese language.

${ }^{10} \mathrm{ti}$ is a clitics of tiay, a loan word from Balinese language.

UNS Journal of Language Studies

Volume 02, Number 02, NOVEMBER 2013 
(8) Aku pada/selapuq ni wah jari menanti leleq oneq. $1^{\text {rst }}$ all/all this already so wait from just now.

'All of me have been waiting for you'

(9)Karin ita pada/səlapuq cica su piaq anti

Again we all Rel so make wait for

'It is all of us who have been waited for'

(10) tiay sami/selapuq jari yirin pəlunguh

$1^{\text {rst-hon }}$ all become follow $2^{\text {nd-hon }}$

'All of me will join you'

(11)Kaji pada/səlapuq yaq tunas pamit.

$1^{\text {rst+hon }}$ all would ask permission

'All of me will be leave you now'

Raden speakers may apply tiay palingih or palingih tiay, tiay paluyguh or paluyguh tiay to communicate to Menak addressee. These pronouns can be interchanged, referring to Raden speakers. Raden and Menak commonly apply these pronouns too, to refer to plural speakers. Number (12)-(13) examplifies such pronouns.

(12) tian polingih/tiay pəlunguh=gin lalo aro bale $=\mathrm{n} \quad{ }^{11}$ maykugin $\quad$ narahay $\quad$ sampi kirayan.

$1^{\text {rst hon plr }}$ FTR go to house link adat leader for submit cow marriage feast

'we are going to visit adat leader's house and offer a caw for marriage feast'

(13) moga-moga titiay pəluyguh ${ }^{12}$ pada maiq pərasaan.

Hopefuly $\quad 1^{\text {rst hon plr }}$ some of you fine feeling

'Hopefully all of us do not underestimate each other'

Bayan addressee has personal pronouns, i.e. diq, epe, sida, palingih, paluyguh, pragayan, and batayan. Pronoun ${ }^{13} \mathrm{diq}$ is generally used by (1) Raden and Menak speaker to communicate to jajarkarang addresse, (2) family member speaker with a higher position communicates to a lower ranked family addressee, i.e. a husband to wife,

\footnotetext{
${ }^{11}$ mayku is a Balinese word borrowed by Sasak language.It refers to a leader and leadership who hold tradition affair.

${ }^{12}$ titiay could combine with only polupuh Mariati (2009:21).

${ }^{13}$ Mariati (2009:34) claimed that intimacy between younger speaker and older addressee may not influence the use of diq and so does the intimacy between the youger or the older.
} 
uncle to aunt, parent to child, older brother or sister to younger one, (3) a higher-social status speaker communicate to a lower addressee, e.g. head village to common teacher, and (4) older speaker communicates to younger addressee who has well-known each other. Number (14) exemplifies such a pronoun.

$$
\begin{aligned}
& \text { (14)mbé timpaq diq mulan anak ronan } \\
& \text { where } \quad 2^{\text {nd }} \text { ascape child person } \\
& \text { 'where do you like to escape one's child' } \\
& \text { (Interview, and observation in Bayan, May 10, 2012) }
\end{aligned}
$$

Sida may be applied by Raden or Menak speaker of any ages when speaking to jajarkarang and penglinsir. Penglinsir in my dialect mənó-məné refers to very important villager, who might be adat or religion leader. This polite pronoun may be used by youn person speaking to an older one. For an example, a child communicates to the mother or father, a wife speaks to her husband, etc. To give a respect, an older speaker of any status may apply this pronoun to communicate with younger in age, and a certain speaker may apply it for a communication with an addressee when they meet for the first time. ${ }^{14}$ Sida could be applied as in (15):

\section{(15)Kəmbé kənó sida kanyan piaq suru=ay siq reyan.}

why alwaysyou ${ }^{2 \text { nd hon }}$ only link order passive by person

'why does the person always command you?

An addressee may receive pəluyguh, pəlingih and pragayanfrom a speaker as far as the addressee is older amongst the aristocrats. Or youn Raden or menaq would apply these pronouns to an old aristocrat. This aristocrate of any ages would receive them from jajarkarang speaker. Raden or menak son-in-law may receive this honorific pronoun from his jajarkarang parent-in-law. A person with higher status i.e. priest, community leader will receive this pronoun from the youn or old speaker. Number (16)(17) exemplifies such pronoun.

(16)Mun pəlingih sətuju, jemaq aku jari bait képén nó If $\quad$ you $^{2 \text { nd }+ \text { hon }}$ agree, tomorrow $\mathrm{I}^{\text {st }}$ become take money that 'If you agree, let me take the money.'

\footnotetext{
${ }^{14}$ In ancient time amongst the common people jajarkarang addressee would had received only this pronoun. Receiving more than sida, e.g. polunguh or pəlingih indicated that addresse wished to increase the family status. This pronoun also have clitics form, such as $d \partial, d a$; and it would be discussed in another reseearch paper of mine.
} 


$$
\begin{aligned}
& \text { (17)Lemaq pəlunguh doay te arep=ay jari pənəyaq masalah nini } \\
& \text { tomorrow } \text { you }^{2 \text { nd+hon }} \text { just pass hope-BEN become middleman problem } \\
& \text { this }
\end{aligned}
$$

'Tomorrow it is you who would become a middleman for this problem'

Batangan as a Bayan pronoun could be applied in an intimate situation. A person with a lower status could speak batangan to the higher one as far as they are in an intimate situation. An older person may also apply it to the young one. Besides adat leader would apply it in a formal situation, e.g. marriage feast, official goverment meeting, death celebration etc. Thus situation may allow the speakers to apply this pronoun. Unfortunately, when the observation, I did not find an example of such a pronoun use.

Pragayan polingih, pragayan poluyguh, dəkaji and paluyguh dakajiis Bayan addressee pronoun. These pronoun may be applied by jajarkarang speaker to Raden addressee. They are commonly applied as in the use of honorific pronouns, e.g. pragayan, palingih, paluyguh and dəkaji. In general this combining pronouns could be apply to an honorification. Number (18)-(21) exemplifies such a pronoun:

(18)Dawəq, pragayan pəlingih juluan.

Please, $2^{\text {nd hon }}$ forward

'Please could you please go forward firstly'

(19)Dawəq, pragayan pəlunguh me $\quad=n \quad=$ dahar juluq.

Please, $2^{\text {nd hon }}$ active link eat ${ }^{\text {hon }}$ first

'Could you please your honourable enjoy your meal'

(20) Wantah dəkaji doay siq laló

Hope $2^{\text {nd hon only }}$ REL go

'It is expected that you Your Majesty are the only who could leave for'

(21)Məlakoq aseq kón pəluyguh dəkaji aginsudi məyentén kón gubuk kami

Ask help to $2^{\text {nd hon }}$ in order to wish drop by to house our

'Your majesty, would you mind visiting our house'

Pronoun pada'you all' refers to addressees in Bayan society. In this community Menaq addressees would receive pada from Raden speaker. Besides Jajarkarang addressees would receive it from Menak and Raden speaker as in (22): 
(22) U kanak pada laló mandiq daus tónó njah.

Hey Children $2^{\text {ndpl }}$ go bathe there

'Hi children, go there to take bath!

(Interview and observation, 2012:20.20 a.m)

Diq-diq belongs to addresses in the community. It is recapitulated to show a plural listener. This pronoun would commonly be applied jajarkarang speaker speaking to the addresses. Thus this pronoun belongs to jajarkarang addresses pronoun as in (23).

(23)Diq-diq siq masi bajay jari laló nonkolay mun kami siq lokaq tejari təpu məђolah kon bale.

You all REL still young become go visit girl brideroom if we REL old become stay still at house

'Hi the youth, it is you all who go to visit the girl family and we stay here better'

Epe-epe and sida-sidais menak and raden plural addresse personal pronouns. These aristocrates would receive epe-epe or sida-sida from the jajarkarang, the common people in Bayan society ${ }^{15}$. Number (24)-(25) exemplifies such pronouns.

(24)lamun epe-epe ni mele məyan, agin $=\mathrm{ku}$ olahay nəykane.

If $2^{\text {nd pol plr }}$ want eat, in order to $1^{\text {rst-clitic }}$ cook now.

'If you want to have a meal, please wait and let me cook for you right away'

(25)Baréh te səygilir jari mənjaga, mun sida-sida wah ləlah bareh aku dait gora mənjaga.

Later we turn become keep, if $2^{\text {nd pol prl }}$ already tired later $1^{\text {rst }}$ and gora keep.

'When you are all tired to watch dog, let me and gora take your turn'

(Interview and observation, 2012:20.20 a.m)

Palingih-palingih or paluyguh-paluyguh refers to menak and raden honorific addressee pronoun ${ }^{16}$. Commonly in Bayan community, north Lombok older aristocrates would be addressed by these pronouns. Jajarkarang may also apply these pronouns to speak to arristocrate communicatees. An example to my observation is as in (26).

(26) piran kəno pəlingih-pəlingih ni yaraqay musyawarah desa nono?

When this $2^{\text {nd hon plr }}$ this make meeting village that

'Your majesty, when would all of you have that village meeting?

${ }^{15}$ Sida-sida resembles to sidə-sidə in meno-məne dialect, a variety spoken in East Lombok.

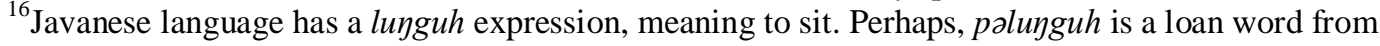
Javanese.

UNS Journal of Language Studies

Volume 02, Number 02, NOVEMBER 2013 
Diq pada is a plural addressee pronoun used by Raden speaker to older and very important jajarkarang addressees. Epe padais also a plural addressee pronoun spoken by jajarkarang to aristocrates, Menak and Raden as in (27) and (28).

(27) $\mathrm{E}$ anak =ku coba diq pada lalo mənan tono juluq jayan wah masak.

Hey child POSS try $2^{\text {nd }}$ plr go eat that firstly meat already cooked.

'Hi children, go down to the kitchen and have your meal as it has been ready for you!'

(28) ${ }^{17}$ Guna kedatə̇an epe pada nini siq jolabaray kanak siq lalo mulay no.

Yes-no Question coming $2^{\text {nd }}$ plt plr this REL report child REL go escape that.

Do some of you come here to report the child escaped by someone?

Beside combining with pada, the above diq and epe could combine with solapuq word, meaning 'all'. Mariati (2009:36) claimed that addressee pronoun combined with pada refers to some addressees; and addressee pronoun combining with salapuqrefers all listeners in a certain comunication.

Bayan speaker and addressee communicate an object, such as person, thing, time, place etc. They would apply personal pronouns such as iya, nya, $e$ which refer to 'he' or 'she'. These pronouns are neutral, meaning that they do not have 'social values'. It means that communicants of any class in Bayan community may apply them without considering social status, age, position, relation etc. (Cf. Mariati, 2009:36).

To show politeness in this community, the communicant would replace the pronouns with clan terms as inaq, amaq, mamiq, papuq etc. Profession terms,i.e. guru, kadus, camat, commonly replace the pronouns. The profession names may have ${ }^{18} a j i$ before the terms as in aji camat, aji kadus, and aji guru.

Other forms are iya-iya, nya-nya, iya pada, nya pada, iya solapuq, and nya salapuq. Raden or menak communicants would apply these pronoun, considering an age. An old speaker may speak to younger addressee when communicating other person. The example (29) is my creation as follows:

(29) An old aristocarate : Nunasay Den, mamiq sampun rauh?

Excuse me short form of Raden $3^{\text {rd hon }}$ already present

\footnotetext{
${ }^{17}$ Guna in Indonesia refers to base form meaning 'use'. It inflects as in berguna 'meaningful' and in menggunakan meaning 'apply'.

${ }^{18} \mathrm{Aji}$ in menó-məne dialect on Sasak language refers to 'price'; in bahasa Indonesia it refers to short form of haji 'pilgrimage to mecca'
} 
'excuse me Den, is mamiq already present?

Younger aristocrate :Nentən, mamiq masih medaran.

Not yet, $3^{\text {rd hon }}$ still have meal

'Not yet, he has been having his meal'.

Iya-iya or nya-nyais actualy plural third person (Mariati, 2009:37). When jajarkarangspeaker speak to menak addressee, to mention other people they would apply the pronouns ${ }^{19}$. Iya pada or nya pada refers to plural third person applied by old speaker to younger addressee. Iya salapuq or nyasalapuq refers to plural third person used by all level of society. The following is some examples of third personal pronouns:

(30) a. Iya lalo yaro oma $n=$ tuluy ama=n Rema. ${ }^{20}$

3rd go farm garden Clt help mister Rema.

'he goes to garden to help mr. Rema.'

b. Nya lalo yaro oma ntuluy aman Rema.

3rd go farm garden CLT help mister Rema.

'he goes to garden to help mr. Rema.'

c. Mun mənayis kucaq brarti mele=nya məyan su kana cica.

If cry as such away indicate wish 3rd POSS art child name of the child.

'When crying in a such way, it means that the child is hungry and want to eat'

d. Apa siq mele $=e$ kanak ni mele=a piaq robes su ajak.

What REL wish 3rd child this, wish 3rd make hit perhaps

Perhaps what the child wish to be hit'

e. Embe tipaq aji guru keq?

Where arrive 3rd teacher particle

Where would he (the teacher) go?'

${ }^{19}$ Third person pronoun in Bayan community has syntactic varieties which may be become an interesting research topic. My research rightnow focuses on social factors of the pronouns.

${ }^{20}$ Aman derives from amaq. Sound [q] dissimilates into [n] for phonem /r/ in Rema. 
f. Iya pada lalo yaro oma $n=$ tuluy aman Rema.

3rd some of them go farm garden Clt help mister Rema.

'Some of them go to help mr. Rema to gardening.'

g. Nya pada lalo yaro oma $n=$ tuluy aman Rema.

3rd some of them go farm garden Clt help mister Rema.

'They go to help mr. Rema to gardening.'

h. Iya səlapuq lalo yaro oma $\mathrm{n}=$ tuluy aman Rema.

3rd all of them go farm garden Clt help mister Rema.

'They go to help mr. Rema to gardening.'

i. Nya səlapuq lalo yaro oma $\mathrm{n}=$ tuluy aman Rema.

3rd all of them go farm garden Clt help mister Rema.

'All of them go to help mr. Rema to gardening.'

\section{c. Raden.menaq.jajarkarang.}

Raden.menaq.jajarkarang. refers to a communication amongst the speaker and addressee with similar social stratification. For example, raden speaker communicate to raden addressee, menaq to menaq and jajarkarang to jajarkarang. In Bayan,old Raden with a high status may apply $a k u$ to younger Raden with lower status, and Menaq communicants may too. For an example, Raden husband speak aku to his wife, to his sons, daughters, your brothers, sisters etc. Thus age and status seem influence the use of $a k u$.

Amongst young Jajarkarang, they could apply aku very commonly. Jajarkarang speakers would apply aku-akuto communicate with a Jajarkarang addressee. Young jajarkarang Bayan speakers could apply tiay-tiay, or kaji-kaji to an older Jajarkarang addressee.

Young Raden or menak speakerscould apply titiayand dawak titiayto an older Raden or menak addressee. Jajarkarang speakers with a low education speak titiay and dawak titiayto an addressee with higher education. Speakers with low social status amongst Raden, menaq and jajarkarang may communicate with titiay and dawok titiay to an addressee with higher social status amongst them. Raden speakers communicating 
with other Raden addressee apply tiay sami. Communication among Raden speakers uses such pronouns tiay palingih or tiaypaluyguh.

\section{CONCLUSION}

Jajarkarang, Menak and Raden are in Bayan society of North Lombok, West Nusa Tenggara, Indonesia. They have their own languages, namely basə jamaq, mənak and raden respectively. In communication they commonly pay attention to social factors: ranks, ages, education level, and status. Until my investigation ended, gender and relation degree may not show us an influence on pronoun use in Bayang community.

Bayan pronouns have various forms, depending on speaker, addressee, and 'object'.


diq, diq-diq, diq pada, diq solapuq, pada, sida, sida-sida, sida-sida doang, sida-sida lonto,

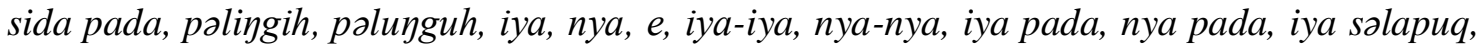
nya salapuq.

In Bayan personal pronoun recapitulation, and combination were found in this research. They could have intensity meaning which may be interesting to investigate.Pronouns have also various forms influenced by syntactic behaviour. Morphological and syntactic aspects of Bayan kuto-kute could be interesting topic to be discussed.

\section{REFERENCES}

Austin, K Peter. 2000. Sasak: Working Papers in Sasak, vol 2. Melbourne: Department of Linguistics \& Applied Linguistics, The University of Melbourne.

Badan Pusat Statistik Kabupaten Lombok Utara. 2010. Kecamatan Bayan dalam Angka.

Harimurti Kridalaksana. 2011. Kamus Linguistik. Edisi Keempat. Jakarta: PT Gramedia Pustaka Media Utama.

Henry Guntur Tarigan. 1983. Prinsip-Prinsip Dasar Sintaksis. Bandung: Penerbit Angkasa.

Mariati. 2009. Pronomina Persona Dalam Tingkatan Sosial Masyarakat di Desa Sukadana Kecamatan Bayan. Mataram: PBI, FKIP Unram. 
Muhammad.2012.ASystem of Sasak Deixis. Surakarta: Linguistik Deskriptif, Universitas Sebelas Maret. $\mathrm{PhD}$ thesis proposal.

Muhammad.2011. Paradigma Kualitatif Penelitian Bahasa. Yogyakarta:Liebe Book Press.

Sudaryanto.1992. Metode Linguistik Ke Arah Memahami Metode Linguistik. Yogyakarta: Gadjah Mada University Press. 